\title{
COMPLETE HYDATIDIFORM MOLE IN A TRIPLET PREGNANCY WITH COEXISTING TWO LIVE FOETUSES- A CASE REPORT AND REVIEW OF LITERATURE
}

\author{
U. Suganya1 , M. P. Kanchana², M. Revathy3
}

1Postgraduate Student, Department of Pathology, Madras Medical College, Chennai.

${ }^{2}$ Professor, Department of Pathology, Institute of Obstetrics and Gynaecology, Madras Medical College, Chennai.

${ }^{3}$ Assistant Professor, Department of Pathology, Institute of Obstetrics and Gynaecology, Madras Medical College, Chennai.

\begin{abstract}
\section{BACKGROUND}

Hydatidiform mole with coexisting twin foetus is an infrequent condition that has been reported in a limited number of cases.(1-4) Only 12 cases of triplet pregnancy with complete mole and two foetuses following ovulation induction, Assisted Reproductive Techniques (ART) and spontaneous conceptions are reported.(1) We describe a case of complete hydatidiform mole with coexisting viable two foetuses following ovulation induction. A 35-year-old lady was pregnant following ovulation induction with clomiphene citrate. A triplet pregnancy with two live foetuses and a complete mole was delivered at 32 weeks of gestation. The antenatal period was uneventful. Continuation of pregnancy as long as maternal complications are absent or controllable can be a safe and rewarding effort in managing the patient.
\end{abstract}

\section{KEYWORDS}

Artificial Reproductive Techniques, Complete Hydatidiform Mole, Preterm, Triplet Pregnancy.

HOW TO CITE THIS ARTICLE: Suganya U, Kanchana MP, Revathy M. Complete hydatidiform mole in a triplet pregnancy with coexisting two live foetuses- a case report and review of literature. J. Evolution Med. Dent. Sci. 2017;6(13):1056-1058, DOI: $10.14260 /$ Jemds/2017/227

\section{BACKGROUND}

The incidence of twin pregnancies with a live foetus and coexisting complete hydatidiform mole is 1 per 22,000 to 100,000 conceptions.(5) Triplet pregnancies with two live foetuses and coexisting complete hydatidiform mole are even rarer. Only 13 cases of hydatidiform mole with two foetuses were reported following ovulation induction, ART and spontaneous conception.(1) And here we present a case of triplet pregnancy with two live foetuses and coexisting complete hydatidiform mole reported in our Institute.

\section{CASE REPORT}

A 35-year-old woman with history of late marriage and primary infertility underwent ovulation induction by clomiphene citrate $50 \mathrm{mg}$ for 5 days in a cycle. She was diagnosed as a hypothyroid and was on T. Eltroxin 50 micrograms once daily. She conceived after 3rd cycle of ovulation induction. Investigations done at $3 \mathrm{rd}$ month of gestational age were found to be within the normal limits except for Beta-HCG, which was elevated up to 1,05,185. Antenatal scan was taken and revealed a twin gestation Fig. 1. She did not have any specific symptoms. She did not continue her regular antenatal checkup. Third trimester scan was taken, showed molar changes (Fig. 2). Then she had a preterm pain at 32 weeks of gestational age. Inj. Betnesol IM was given. On examination uterus overdistended, mildly acting and multiple foetal parts were palpated.

Financial or Other, Competing Interest: None.

Submission 07-11-2016, Peer Review 28-01-2017,

Acceptance 04-02-2017, Published 13-02-2017.

Corresponding Author:

Dr. U. Suganya,

\#523, MMC Ladies Hostel,

Opp. to Chennai Central,

Chennai-600003.

E-mail:drsuganya19@gmail.com

DOI: $10.14260 /$ jemds $/ 2017 / 227$

\section{(c) $(1) \$$}

As there was no progress in labour, scan was done and first baby was found to be in transverse lie. Emergency LSCS was done and delivered two female preterm babies. Twin I weighed 2010 grams and Apgar was 8/10. Twin II weighed 3213 grams and Apgar was 9/10. Also delivered monochorionic diamniotic placenta with a complete vesicular mole. Both the babies survived well. Postpartum period was uneventful.

The placenta with molar changes are subjected to histopathological examination. Macroscopically, the placenta was monochorionic diamniotic with a distinct groove in between and showed cord attachment. Attached to this was a complete vesicular mole composed of fluid filled vesicles covered by a membrane (Fig. 3).

Microscopically, molar placenta showed oedematous avascular chorionic villi with circumferential proliferation of trophoblast. There was a moderate degree of trophoblastic proliferation with atypia (Fig. 4). Other 2 normal appearing placentae and cords showed normal histology. As p57 will be positive in normal placenta and partial mole and absent in complete mole, p57 was done and found to be negative (Fig. 5).

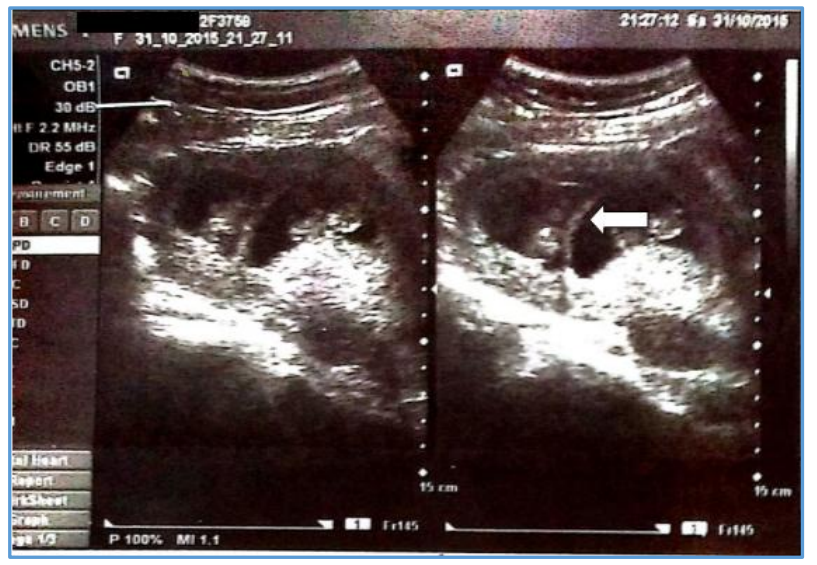

Figure 1. Arrow shows Membrane between Two Gestational Sac indicating Multiple Gestations 


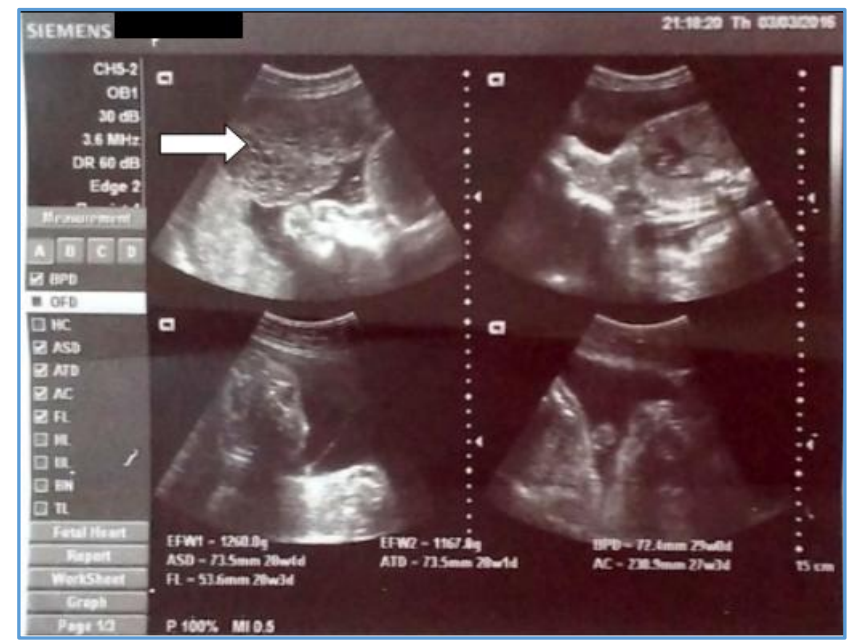

Figure 2. Arrow shows Vesicular Changes at Posterior Fundal Pole

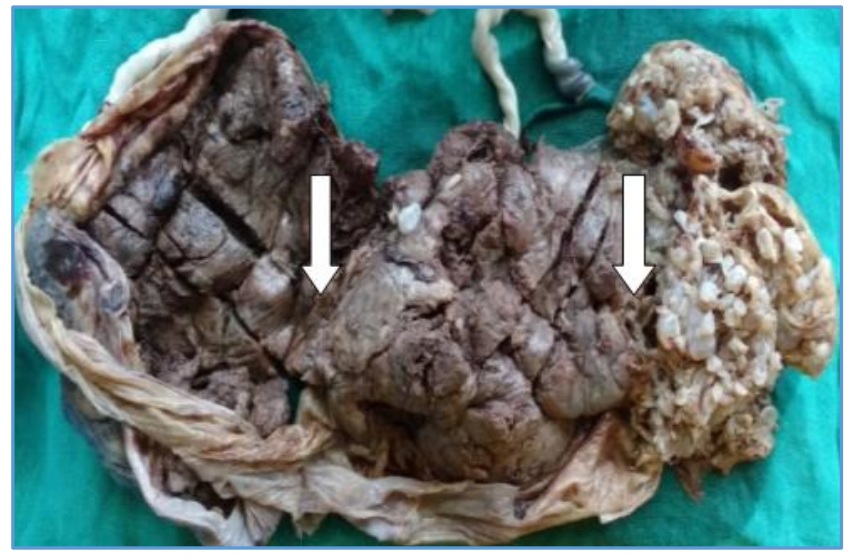

Figure 3. Arrows show Grooves in between Placentae

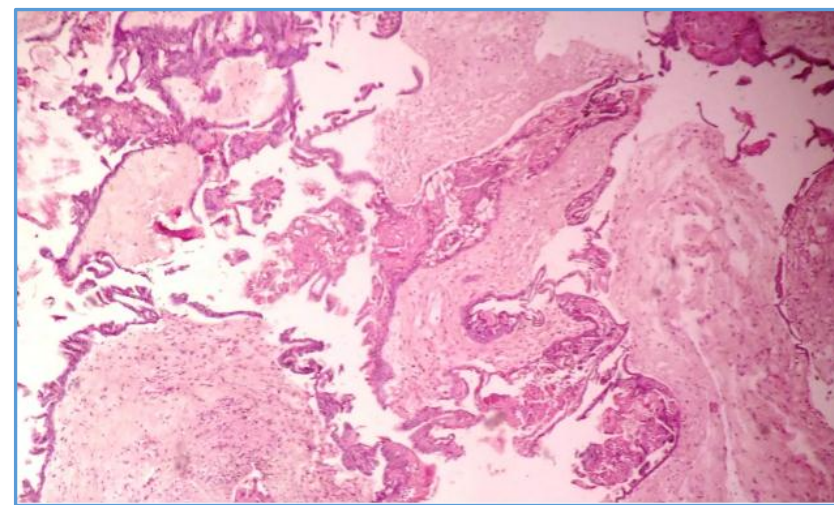

Figure 4. Shows Oedematous Avascular Chorionic Villi with Circumferential Proliferation of Trophoblast

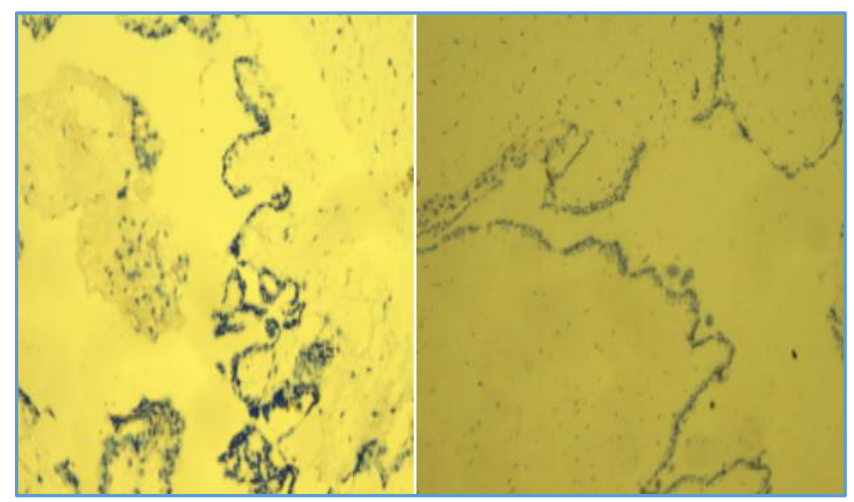

Figure 5. P57 Negative in Trophoblasts and in Stromal Cells

\section{DISCUSSION}

Triplet pregnancy with coexistence of complete hydatidiform mole is a rarer condition, which has been reported previously in 13 cases (as summarised in the Table).(1) For past 5 years, we have reported 4 cases of multiple pregnancies with hydatidiform change. Among them 3 cases were twin pregnancies with single live foetus and 1 hydatidiform mole. This was the first case we reported a triplet pregnancy with 2 live foetuses and coexisting complete hydatidiform mole.

\begin{tabular}{|c|c|c|c|c|}
\hline Case & $\begin{array}{l}\text { Hormone } \\
\text { Therapy }\end{array}$ & $\begin{array}{c}\text { Gestational Age at } \\
\text { Delivery } \\
\text { (In Weeks) }\end{array}$ & $\begin{array}{c}\text { No. of } \\
\text { Surviving } \\
\text { Foetuses }\end{array}$ & $\begin{array}{c}\text { Maternal } \\
\text { Complications }\end{array}$ \\
\hline 1. Sauerbrei et al $(6)$ & Clomiphene & 22 & 0 & Vaginal bleeding, preeclampsia at 22 weeks \\
\hline 2. Ohmichi et al(7) & $\mathrm{hMG}+\mathrm{hCG}$ & 17 & 0 & Vaginal bleeding, persistent trophoblastic tumour \\
\hline 3. $\quad$ Azuma et al(8) & $\mathrm{hMG}+\mathrm{hCG}$ & 19 & 0 & Vaginal bleeding \\
\hline 4. $\quad$ Van de Geijn et al(9) & GIFT & 24 & 0 & Vaginal bleeding \\
\hline 5. Shahabi et al (10) & Clomiphene & 17 & 0 & $\begin{array}{l}\text { Persistent trophoblastic tumour, choriocarcinoma, } \\
\text { lung metastasis, hyperthyroidism }\end{array}$ \\
\hline 6. Shozu et al(11) & IVF - ET & 15 & 0 & Vaginal bleeding, persistent trophoblastic tumour \\
\hline 7. Higashino et al(12) & $\begin{array}{l}\text { Clomiphene + } \\
\text { FSH + hCG }\end{array}$ & 15 & 0 & $\begin{array}{l}\text { Preeclampsia, secondary hyperthyroidism, } \\
\text { persistent trophoblastic tumour }\end{array}$ \\
\hline 8. $\quad$ Amr et al ${ }^{(13)}$ & Clomiphene + hCG & 30 & 1 & None \\
\hline 9. Rajesh et al(14) & None & 24 & 0 & Vaginal bleeding \\
\hline 10. Malhotra et al(15) & None & 21 & 0 & Vaginal bleeding \\
\hline 11. Takagi et al(5) & $\mathrm{hMG}+\mathrm{hCG}$ & 28 & 2 & Persistent trophoblastic tumour, lung metastasis \\
\hline 12. Bovicelli et al $(16)^{(16)}$ & IVF - ET & 31 & 1 & None \\
\hline 13. P. C. Ko et al ${ }^{(1)}$ & IVF - ET & 33 & 2 & Preeclampsia \\
\hline 14. Present case & Clomiphene & 33 & 2 & None \\
\hline \multicolumn{5}{|c|}{$\begin{array}{l}\text { Table 1. Cases of Triplet Pregnancies consisting of a Complete } \\
\text { Hydatidiform Mole and Two Foetuses: Maternal and Foetal Outcomes (1) }\end{array}$} \\
\hline
\end{tabular}

hMG = human menopausal gonadotropin; hCG = human chorionic gonadotropin; GIFT = gamete intrafallopian transfer; IVF-ET $=$ in vitro fertilisation and embryo transfer. 
The incidence of a complete Hydatidiform mole with two coexisting foetuses was unknown due to the rarity of case reports. It might be misdiagnosed as a growing subchorionic haematoma or a twin gestation along with a partial molar pregnancy. Ovarian medical stimulation due to infertility is one of the major risk factors, which need to be considered. The infertility factor and the importance of pregnancy make treatment decision difficult for the family and medical staff. Gestational Trophoblastic Disease (GTD) is divided into several groups including: (1) Complete/partial Hydatidiform mole; (2) Persistent/invasive gestational trophoblastic neoplasia; (3) Choriocarcinoma; (4) Placental site trophoblastic tumour. It is known that the risk of GTD, distant metastasis and chemotherapeutic treatment increase in a complete molar pregnancy with a coexisting live foetus. GTD incidence was shown to be as high as $55 \%$, if pregnancy was chosen to be continued. Severe clinical symptoms such as vaginal bleeding, pelvic pain and pressure, hyperthyroidism, hyperemesis gravidarum, anaemia and a rapidly growing uterus are what make the patient turn up for a medical evaluation. Symptoms worsen as the number of coexisting foetuses increase. In a molar pregnancy with a single coexisting foetus, full-blown hyperthyroidism occurs in $0.05 \%$ and the incidence increases with increased coexisting foetal number. Preterm birth before 28 weeks gestation is estimated to occur in $62 \%$ of cases. The rate in more than one coexisting foetus is not known, but estimated to be higher. Spontaneous foetal loss was estimated to occur in $62 \%$ of cases. The incidence seems to be higher in cases with more than one coexisting foetus.(17)

\section{CONCLUSION}

Complete hydatidiform mole with two live foetuses was a rare condition and mostly ends up in poor outcome. This patient had a history of primary infertility and ovulation induction delivered two live babies and a complete mole at 32 weeks of gestation. This case is presented for its rarity and favourable outcome.

\section{REFERENCES}

[1] Ko PC, Peng HH, Soong YK, et al. Triplet pregnancy complicated with one hydatidiform mole and preeclampsia in a 46,XY female with gonadal dysgenesis. Taiwan J Obstet Gynecol 2007;46(3):27680.

[2] Kwon HE, Park EJ, Kim SH, et al. A case of twin pregnancy with complete hydatidiform mole and coexisting fetus following IVF-ET. J Assist Reprod Genet 2002;19(3):144-8.

[3] Jones WB, Lauersen NH. Hydatidiform mole with coexistent fetus. Am J Obstet Gynecol 1975;122(3):267-72.
[4] Matsui H, Sekiya S, Hando T, et al. Hydatidiform mole coexistent with twin live fetus: a national collaborative study in Japan. Human Reprod 2000;15(3):608-11.

[5] Takagi K, Unno N, Hyodo HE, et al. Complete hydatidiform mole in a triplet pregnancy coexisting two viable fetuses: case report and review of the literature. J Obstet Gynaecol Res 2003;29(5):330-8.

[6] Sauerbrei EE, Salem S, Fayle B. Coexistent hydatidiform mole and live fetus in the second trimester: an ultrasound study. Radiology 1980;135(2):415-7.

[7] Ohmichi M, Tasaka K, Suehara N, et al. Hydatidiform mole in a triplet pregnancy following gonadotropin therapy. Acta Obstet Gynecol Scand 1986;65(5):523-4.

[8] Azuma C, Saji F, Takemura M, et al. Triplet pregnancy involving complete hydatidiform mole and two fetuses: genetic analysis by deoxyribonucleic acid fingerprint. Am J Obstet Gynecol 1992;166(2):664-7.

[9] Van de Geijn EJ, Yedema CA, Hemrika DJ, et al. Hydatidiform mole with coexisting twin pregnancy after gamete intra-fallopian transfer. Hum Reprod 1992;7(4):568-72.

[10] Shahabi S, Naome G, Cobin L, et al. Complete hydatidiform mole and coexisting normal fetuses. A report of two cases with contrasting outcomes. J Reprod Med 1997;42(11):756-60.

[11] Shozu M, Akimoto K, Kasai T, et al. Hydatidiform moles associated with multiple gestations after assisted reproduction: diagnosis by analysis of DNA fingerprint. Mol Hum Reprod 1998;4(9):877-80.

[12] Higashino M, Harada N, Hataya I, et al. Trizygotic pregnancy consisting of two fetuses and a complete hydatidiform mole with dispermic androgenesis. Am J Med Genet 1999;82(1):67-9.

[13] Amr MF, Fisher RA, Foskett MA, et al. Triplet pregnancy with hydatidiform mole. Int J Gynecol Cancer 2000;10(1):76-81.

[14] Rajesh U, Cohn MR, Foskett MA, et al. Triplet pregnancy with a coexisting complete hydatidiform mole of monospermic origin in a spontaneous conception. BJOG 2000;107(11):1439-42.

[15] Malhotra N, Deka D, Takkar D, et al. Hydatidiform mole with coexisting live fetus in dichorionic twin gestation. Eur J Obstet Gynecol Reprod Biol 2001;94(2):301-3.

[16] Bovicelli L, Ghi T, Pilu G, et al. Prenatal diagnosis of a complete mole coexisting with a dichorionic twin pregnancy: case report. Hum Reprod 2004;19(5):1231-4.

[17] Polonsky A, Olteanu I, Ben-David M, et al. Viable triplet pregnancy coexisting with a complete molar pregnancy. Clinical Case Rep 2016;4(3):247-9. 